\title{
Petrogenetic links between lepidolite-subtype aplite-pegmatite, aplite veins and associated granites at Segura (central Portugal)
}

\author{
Isabel Margarida Horta Ribeiro Antunes ${ }^{a, *}$, Ana Margarida Ribeiro Neiva ${ }^{b}$, João Manuel Farinha Ramos ${ }^{c}$, \\ Paulo Bravo Silva ${ }^{\mathrm{c}}$, Maria Manuela Vinha Guerreiro Silva ${ }^{\mathrm{b}}$, Fernando Corfu ${ }^{\mathrm{d}}$ \\ a Polytechnic Institute of Castelo Branco, 6001-909 Castelo Branco, Portugal \\ b Department of Earth Sciences and Geosciences Centre, University of Coimbra, 3000-272 Coimbra, Portugal \\ c LNEG National Laboratory of Energy and Geology, Apartado 1089, 4466-956 S. Mamede de Infesta, Portugal \\ d Department of Geosciences, University of Oslo, PB1047, Blindern N-0316, Norway
}

\section{A R T I C L E I N F O}

\section{Article history:}

Received 18 July 2012

Accepted 29 December 2012

\section{Keywords:}

Aplites

Lepidolite-subtype aplite-pegmatites

Lepidolite

Montebrasite

Sn-Nb-Ta oxide minerals

Parent granite

Crystal fractionation

\begin{abstract}
A B S T R A C T
In the Segura area, Variscan S-type granites, aplite veins and lepidolite-subtype granitic aplite-pegmatite veins intruded the Cambrian schist-metagraywacke complex. The granites are syn D3. Aplite veins also intruded the granites. Two-mica granite and muscovite granite have similar ages of $311.0 \pm 0.5 \mathrm{Ma}$ and $312.9 \pm 2.0 \mathrm{Ma}$ but are not genetically related, as indicated by their geochemical characteristics and $\left({ }^{87} \mathrm{Sr} /{ }^{86} \mathrm{Sr}\right)_{311}$ values. They correspond to distinct pulses of magma derived by partial melting of heterogeneous metapelitic rocks. Major and trace elements suggest fractionation trends for: (a) muscovite granite and aplite veins; (b) two-mica granite and lepidolite-subtype aplite-pegmatite veins, but with a gap in most of these trends. Least square analysis for major elements, and modeling of trace elements, indicate that the aplite veins were derived from the muscovite granite magma by fractional crystallization of quartz, plagioclase, K-feldspar and ilmenite. This is supported by the similar $\left({ }^{87} \mathrm{Sr} /{ }^{86} \mathrm{Sr}\right)_{311}$ and $\delta^{18} \mathrm{O}$ values and the behavior of $\mathrm{P}_{2} \mathrm{O}_{5}$ in $\mathrm{K}$-feldspar and albite. The decrease in $\left({ }^{87} \mathrm{Sr} /{ }^{86} \mathrm{Sr}\right)_{311}$ and strong increase $\left(1.6 \%\right.$ ) in $\delta^{18} \mathrm{O}$ from two-mica granite to lepidolite-subtype aplite-pegmatite veins, and the behaviors of $\mathrm{Ca}, \mathrm{Mn}$ and $\mathrm{F}$ of hydroxylapatite indicate that these veins are not related to the two-mica granite.

The occurrence of amblygonite-montebrasite, lepidolite, cassiterite, columbite-(Fe), columbite-(Mn) and microlite suggests that lepidolite-subtype granitic aplite-pegmatite veins are highly differentiated. Montebrasite shows a heterogeneous Na distribution and secondary lacroixite was identified in some montebrasite areas enriched in Na. Unusual Mn > Fe cassiterite is zoned, with the alternating darker zones being strongly pleochroic, oscillatory zoned, and containing more $\mathrm{Nb}$ and Ta than the lighter zones. Inclusions of muscovite, apatite, tapiolite-(Fe), ixiolite and microlite are present both in lighter and darker zones of cassiterite. It shows exsolutions of columbite-(Fe), columbite-(Mn,Fe) and columbite-(Mn), particularly in darker zones.
\end{abstract}

(c) 2013 Elsevier GmbH. All rights reserved.

\section{Introduction}

The mineralization processes related to granites, pegmatites and hydrothermal veins involve the enrichment of rare elements (e.g., Be, Ta, $\mathrm{Li}, \mathrm{Sn}, \mathrm{Bi}, \mathrm{W}, \mathrm{Mo}, \mathrm{Cu}$ ) and volatiles in late residual magma, or their enrichment in volatile phases in the final stages of magmatic crystallization (Beurlen et al., 2001). Almost all rare-element pegmatite types (low temperature and pressure) are associated with highly fractionated peraluminous granites (Černý, 1992) and are accepted as the products of magmatic differentiation from large granite bodies (e.g., Černý, 1992; Leal Gomes, 2006; Neiva et al., 2008, 2012; Neiva and Ramos, 2010).

\footnotetext{
* Corresponding author. Tel.: +351 964219682; fax: +351272339901.

E-mail address: imantunes@ipcb.pt (I.M.H.R. Antunes).
}

However, this mechanism is difficult to test for pegmatites (e.g., Neiva et al., 2008, 2012; Neiva and Ramos, 2010), due to the presence of B, F, P and Li fluxes, which are involved in the crystallization of tourmaline, topaz, montebrasite-amblygonite, lepidolite, and influence the crystallization of cassiterite, columbite-tantalite and microlite (e.g., Linnen and Cuney, 2005). These pegmatite minerals are important indicators, as the origin of the pegmatites must be responsible for the occurrence of all their minerals. Some examples of lepidolite-subtype pegmatites do not show this mineral association, as the volatile-rich fluids are stable at relatively low temperatures and commonly migrate to great distances from their plutonic sources (Černý et al., 2005). Therefore, parent granite and pegmatites can be spatially separated (e.g., Currie et al., 1998).

The aplite-pegmatite veins from Segura are REL-Li pegmatites and belong to the LCT family (sensu Černý and Ercit, 2005), which is characterized by the enrichment in Li, Cs and Ta. In central Portugal, 